Information Management and Business Review

Vol. 3, No. 4, pp. 198-205, Oct 2011 (ISSN 2220-3796)

\title{
Organization Performance Influenced by the BSD and Consultative Management Style
}

\author{
Muhammad Yameen ${ }^{1}$, Syed Kamran Ali Shahㄹ, Jam Javed Iqbal ${ }^{1},{ }^{*}$ Adeel Razaq² M. Suleman Sabir², Adil Sohail², \\ Zafar Ullah ${ }^{2}$ \\ ${ }^{1}$ Al-Khair University (AJK) Main Campus Bhimber \\ ${ }^{2}$ Iqra University Islamabad, Pakistan \\ *adeel_razaq@hotmail.com
}

\begin{abstract}
The purpose of this study is to investigate the relationship among Balanced Scorecard, consultative management style, participative management style and organization size with organizational performance. All the variables are highly correlated with each other. This is an empirical study and data is collected from 100 respondents of service sector from Azad Kashmir. We used five likert scales to collect data from the respondents and data analyzed through SPSS. The result showed that there is a significant positive correlation among variables. This study also indicates that effective management style is necessary for improving the performance of organization. The result indicates that Balanced Scorecard has significant impact on performance of organization. Organization use BSC to handle the complexity and challenges that management faces during their operations. The collection of data is from small area due to time constraint. In the future comparative study can be done with other organizations for better analysis of results.
\end{abstract}

Keywords: Balanced Scorecard, Participative Management, Consultative Management, Organization Size, Organization Performance

\section{Introduction}

Organizations are becoming worldwide due to advancement of technology and organizations want to grasp new opportunities in the different countries. Therefore, competition among organizations increases and economy is also becoming knowledgeable (Cappelli, 2000). Performance also requires how management and leader make decisions and policies with respect to environmental changes and requirement of the business (Martell et al., 1996). Organization also requires skills for making decision and running smoothly. These people have the responsibilities to develop the decision-making skills and performance evaluation techniques, which promote the performance of the organization (Dev and Olsen, 1989). Organization's performance is affected by the size and structure of organization. Every organization has four basic objectives that include satisfaction of customer, growth, development of employees and profitability (Harrington and Ottenbacher, 2009). All these objectives are interlinked. Service organization required trained and satisfied employees because employees provide services to diverse customers who have different norms and values (Garvin, 2000). There are different management styles, which have affect on performance of organization. These management styles are participative management style, consultative management style, directive management style (Northouse, 2004). The management develops the communication pattern among the employees. Sometime organization uses open door policy and through this policy every employee can contact with the senior managers.

Participative management style helps in sharing the knowledge among the employees, which leads to the innovation and efficiency of the organization increases. This style empowers the employees and they feel ownership in the organization (Northouse, 2004). Employees' efficiency increases and absenteeism decreases which show their commitment with organization. Participative management is good for attracting skilled and trained workforce (Brown, 2000). Participative management style reduces the cost of organization because there is no requirement of supervisor in the organization. Participative management reduces the conflict and ambiguity and time do not spend on waste discussion. Due to sharing the knowledge, employees get knowledge of other department (Harrington, 2004). This style requires a change in the culture of organization. 
Consultative management style is an approach in which management usually focus on obtaining the services of other people. These people gain compensations or rewards for the sake of their work. Management use this style from the permission of other people who are affecting from their decision (Harrington, 2004). Consultative management creates synergy, which has more solution as compared to individual contribution, but decisions are made by the top management (Gmur, Bartelt and kissling, 2010). This style also supports positive conflict which creates the new opportunity for the organization and performance affect from such process. Balance Scored approach is becoming core management system for different organization because it is used to set goals of individual and team (Young, et al., 1998). This approach is also useful for providing the feedback of different department and it is a critical for organization success. Balanced scorecard is helpful in balancing the short term and long-term objectives because when managers integrate different indicators than they gain different information, which can be useful for decision-making (Brown, 2000). Balanced scorecard approach has two benefits that are management control and strategic control.

Participative and consultative approaches are useful in enhancing the performance of organization because a sense of ownership develops among the employees and top management emphasize in the involvement of employees in every activity at each level. Organization size influences the structure of organization in perspective of resources, complexity and information sharing. Management can use Balanced scored approach in setting the goals, distribution of resources, pay packages to the employees and planning the budget of employees as an individual and because of team at each level of the organization. This approach also use as a performance indicator.

\section{Literature Review}

In the growing economy, there is continuous improvement in hospitality industry because managers in the service industry are ready for the improvement in the strategies and decision-making styles. Decision-making is important whether the person is a manager or an ordinary employee or frontline employee. Different assumptions made by different authors includes; the cause and effect of environment and relationship which should be understood (Mintzberg, 1973), the information which is required to understand the relationships is not specific to other parts of the organization (Cloudhury and Sampler, 1997) and the subordinates accept the orders from the managers and perform the work (Bryson and Bromiely, 1993).

In participative management, leaders or managers involve subordinates in the decision-making. A leader or manager takes suggestions and opinions from the subordinate for decision-making (Northouse, 2004). Participative management style is important and has positive effect on the employees. It increases job satisfaction and motivation of the employees to do the job perfectly and increases the quality of the decision (Ogbeide, et al., 2008; Smylie, et al., 1996). Decision-making has different perspectives and it can be categorized in three different types, which are analysis, judgment and participative tactics. Harrington and Ottenbacher (2009) suggested in hospitality industry mangers can make significant decisions. It is found that there are direct and interacting relationships among several features with decision-making plans. The relevant characteristics include fast decision-making, riskiness, difficulty, changing environment, decision maker and support for the decision and resistance. It is also found that participative management is useful for the high valued services or business sector. In spite of this fact that participative management approach used in different organization in different way from the other organizations (Harrington, 2004). The organizations dependency on participative management is due to the participations of the employees in their capacity is more and becomes necessary due to the working environment and the dependency between employees (Oosthuizen and Adeline, 1999). Northouse (2004) claims that giving authority or empowering the employees encourages them to accomplishment of goals. In the new era the organizations cannot manage by capital, technology but it also requires how employees are handled (Harrington, 2004). In participative management approach employees from different field think about the same thing to find out the solutions but in different ways.

In horizontal structure the involvement of the employees give them opportunity to know about different departments, team members and the stakeholders (Forbes and Milliken, 1999). In vertical structure the 
involvement of the employees relates to the hierarchy of the management from top level to the lower level (Barringer and Bluedorn, 1999). Simons, et al. (1999) claims that the relationship between the horizontal and vertical structure does not show the success when implemented. It is necessary to discuss on the involvement of the employees on horizontal structure in hospitality sector and differences in the vertical structure for the employees, which should be completely understood (Harrington, 2004). Ottenbacher and Harrington (2008) present a matrix to find out the horizontal and vertical structure for an organization for the involvement of the employees. The diverse nature of involvement of employees will provide them more information and knowledge for decision making and finding the alternatives (Forbes and Milliken, 1999; Simons, et al., 1999). If the organizations don't use the downward approach in decision making then the teams will not able to perform the work properly (Dooley and Fryxell, 1999). Involvement of top management increases the success rate of organization (Chorengel and Teare, 1994; Schmelzer and Olsen, 1994; Teare, et al., 1998; Okumus, 2003; Harrington, 2004). Harrington (2004) and Okumus (2003) discussed the relations between participative management approach, the organizational structure and the involvement of employees in achieving the organization's goals and objectives.

Organizations in the world know the value of the consultative approach to find out new talent (Make coaching count, 2006). In consultative management approach managers try to make employees realize that their thoughts about the organization are credible and their opinions have value but the final decision is made by the top management (Learnmangement2.com). The decisions are taken by the board which consists of top management and area managers to be successful (Gmur, Bartelt and kissling, 2010).The organizational size also matters a lot for the success of the organization. The small size organizations or business face several challenges like advancement in the technology, crisis, competitors and globalization and changes in the demands of the customers due to scarce resources (Belardo and Belardo, 2002 ;). The organizations development in the small organizations is less as those organizations have fewer resources (Garvin, 2000). The small business or organizations provide more opportunities for new jobs (The European Observatory for SMEs, 1995). The organization size also matters for the communication and managing it simply (Ghobadian and Gallear, 1997).

The Balanced Scorecard was developed by the Robert Kaplan and David Norton in 1990. The effective improvement in Balanced Scorecard was done by Kaplan and Norton and Niven in different years which lead to cause and effect diagram where every element of performance is linked to another (Valmohammadi and Servati, 2011). The Balanced Scorecard which measures the different strategies and focus on the future and how the organization will make its objectives (Brown, 2000). For Balanced Scorecard a generalized process is difficult to make so it is good every organization make its own methods (Haapasalo, Ingalsuo and Lenkkeri, 2006). There is no or little research done on these variables for measuring the organization performance.

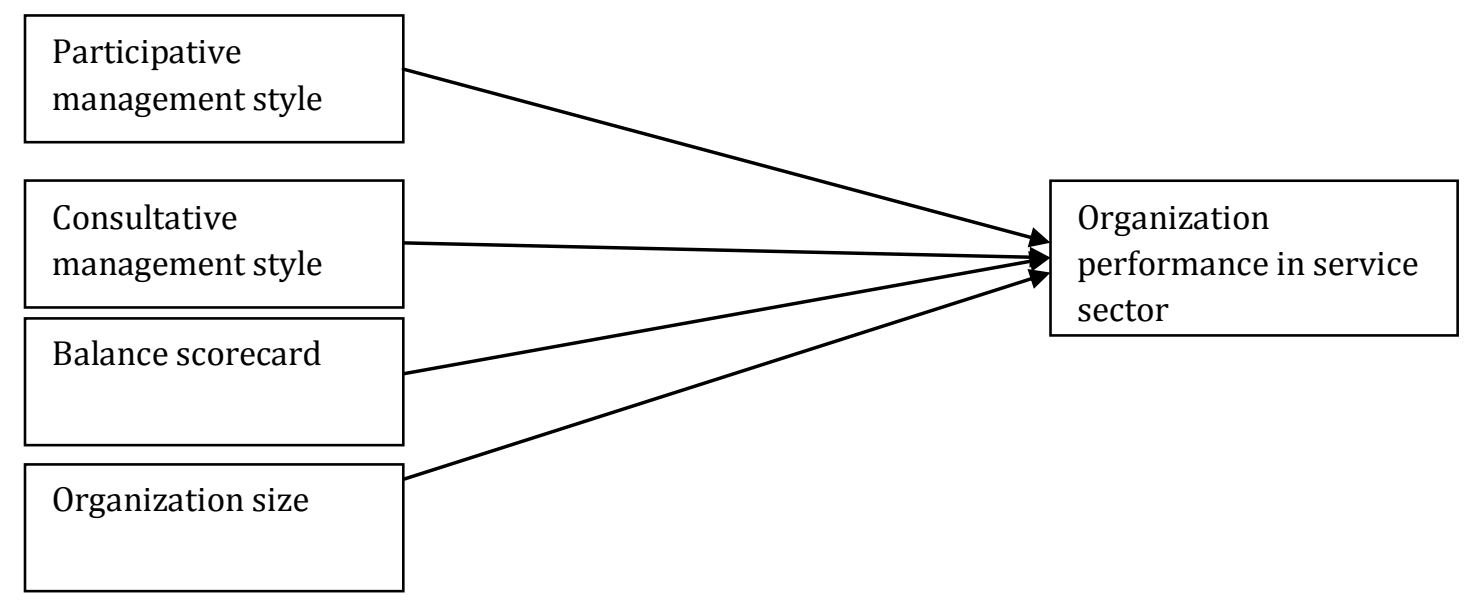




\section{Hypotheses:}

H1: Organization's performance is positively influenced by the participative management style.

H2: Consultative management style has positive impact on organization performance.

H3: Balanced scorecard approach has positive effect on the performance of organization.

H4: Organization size has positively affected on the organization's performance.

\section{Research Methodology}

The purpose of this research is to analyze the influence of different management styles on organizational performance because management styles influence the decision-making and involvement of employees in the activities. This is an empirical research based on the primary data collected from hundred $(\mathrm{N}=100)$ employees in banking sector of Azad Kashmir and 6 different banks are selected for collection of data. The questionnaire is discussed with supervisor and other related people for further guidance. Validity is a helpful tool for measuring the instrument which is used in data collection. Cronbach's Alpha is commonly used for reliability of data collections. Instrument consists of two parts. First part contains the general profile of the respondent and second part includes the items about the variables. Questionnaire has 20 items, which contains 4 items about each variable. Five Likert scale is used to collect data which ranging from 1-5.

\section{Reliability Statistics}

\begin{tabular}{lc}
\hline Variables & Cronbach's Alpha \\
\hline Balanced Scorecard & .825 \\
Participative management Style & .709 \\
Consultative Management Style & .610 \\
Organization Size & .613 \\
Organization Performance & .859 \\
\hline
\end{tabular}

Cronbach's alpha is used normally to check the reliability of data. If the value of cronbach's alpha is 0.60 or greater than it is considered data is relevant and reliable, otherwise it is considered unreliable which present abnormal result.

Table. 1 Descriptive Statistics of study variables

\begin{tabular}{lcc}
\hline \multicolumn{1}{c}{ Variables } & Mean & Std. Deviation \\
\hline Organizational Performance & 3.792 & .8536 \\
Balanced Scored approach & 4.0800 & .78486 \\
Participative Management Style & 3.81 & .769 \\
Consultative Management Style & 3.52 & .744 \\
Organizational Size & 3.550 & 1.1203 \\
\hline
\end{tabular}

Table 1 shows the mean and standard deviation of the variables. Balanced scorecard has high value from other variables which means respondents have give response in a strongly agree whereas organization size has high value of standard deviation from the remaining variables.

Table. 2 Correlations Analysis of study variables

\begin{tabular}{llllll}
\hline & Avg. DV & Avg. BSC & Avg. Parti & Avg. Consul & Avg. OS \\
\hline Avg. DV & 1 & & & & \\
Avg. BSC & $.948^{* *}$ & 1 & & & \\
Avg. Parti & $.764^{* *}$ & $.785^{* *}$ & 1 & & \\
Avg. Consul & $.800^{* *}$ & $.765^{* *}$ & $.782^{* *}$ & 1 & 1 \\
Avg. OS & $.834^{* *}$ & $.768^{* *}$ & $.717^{* *}$ & $.829^{* *}$ & \\
\hline
\end{tabular}


Table 2 indicates the correlation among balanced scorecard, consultative management style, and participative management style and organization size with organization performance. If the values of variables are between +1 and -1 then it is considered that variables are positively correlated. The value of $\mathrm{R}$ which is coefficient of determination and its value is 0.96 . This means that 0.96 of the variance in organization performance can be accounted for by Balanced Scorecard, Consultative management, Participative management and organization size. $\mathrm{F}$ is significant between $0.01-0.05$ which verify that 0.96 of variance in organization performance is due to Balanced Scorecard, Consultative management, Participative management and organization size. The result of regression model summary supports the hypothesis because value of adjusted $\mathrm{R}$ is less than from the $\mathrm{R}$ and $\mathrm{R}$ square. $\mathrm{P}$ value of the variables is between .01-.05 which is significant

Discussion: Our study is based on participative management style, consultative management style, organization size and balanced scorecard which influence the organization performance. The reliability test shows the Cranach's alpha value which is more than .75 and it identify that data is relevant and reliable. The finding from the empirical data and literature indicate that the entire variables are correlated. The manager and management in service sector realize the need of participative management style because it provides a motivation and satisfaction to the employees (Oosthuizen and Adeline, 1999). The participative management success depends upon the way how managers apply it (Maisela, 1995). Participative decisions should not be reserved for any employee and when decisions are taken every employee should be there (Oosthuizen and Adeline, 1999). Mean of participative management style has high value $(M=3.792$, Std. deviation=0.8536) which indicate that participative management style has a major impact on employee's motivation level because they are involved in making decision and strategy of the organization. Table 1 shows the value of mean and standard deviation which is above average and significance is of $\mathrm{P}<.05$. So literature and results prove that $\mathrm{H} 1$ is acceptable.

Consultative management style is mostly used by the managers for giving the employees realization of their useful role of the organization and job enlargement is one way to prove (Sorensen and Minahan, 2011). Consultative management provides the input for making polices from employees and after consideration it is proven by the management (Reddick, 2011). Consultative model helps in enhancing the policy making and efficiency of organizations (Kolsaker and Lee- Kelley, 2008). The consultative approach is used to convince the other employees and departments and less time is require for the work done properly (Davis, 2001). The result indicate that $\mathrm{H} 2$ also significant and positive correlated to the organization's performance $(\mathrm{M}=3.52$, Std. deviation=.744, $\mathrm{B}=.068, \mathrm{P}=.039$ ).

To find out the organization performance the Balanced Scorecard is one approach to measure the performance effectively if data is collected systematically (Niven, 2005). The Balanced Scorecard at first was used to measure the learning, growth and business process (Malmi, 2001). The Balanced Score card is also used to measure the cause and effect relationship of performance and the policies (Lawrie and Cobbold, 2004). With Balanced Scorecard is used to communicate and control the strategies which should be implemented (Valmohammadi and Servati, 2011). Balanced score d is also used to control the process and management. Balanced scored is a handy tool to measure the performance of employees and organizations.

The result and literature also support to H3: Organization size also enhances the performance of the organization because organizational size affects the structure which affects the performance (Joiner, 2007). The changes in the organization must be consider size as the employees always took opportunities where they find better salary and facilities ( Marsick and Watkins, 2003). Those organizations which are small in size face difficulties in learning/ improvement process which results in poor performance and disorders (Snyder and Cummings, 1998). The organizations with the small size are helpful where individuals are operating like in construction, healthcare and agriculture sector (Nafukho, Graham and Muyia, 2009). But organization size has advantages for small and large organization in their own perspective. The result and literature proves $\mathrm{H} 4$. The value of mean of organization size is above average which support $\mathrm{H} 4 \mathrm{M}=3.55$, Std. deviation=1.1203) with 0.000 significance. All the hypotheses are supported by the statistical results and literature. 


\section{Conclusion}

The focus of the study is to understand the relationship between the management styles and Balanced Scorecard approach during action planning implementation and organization performance. Balanced scorecard is strategic tool to measure the performance of organization. Balanced Scorecard is used to convey and manage the implementation of strategies. BSC is also used to control the process and management system. Rewards and compensation provided on the bases of BSC because it shows the performance of each employee. Organization size affects the performance of organization because in large organization decision making is complex and time consuming where as in small organization decision making is easy and flexible. The involvement of top level management in decision making of Small or large organizations is important. Participative management style is a strong predictor for measuring the level of participation. If management understands that their employees are industrious and loyal to the organization than their trust increases among the top management and sense of empowerment increases among employees. The performance, commitment and satisfaction of the employee's increases due to the implementation of participative management style applied effectively. Organizations across the globe have recognized the value of adopting such a consultative one-to-one tailored approach when developing their key capacity. However, despite having been just about for a considerable amount of time, this type of management growth still does not have a formal, internationally recognized endorsement scheme. All the variables are useful for satisfy and motivate the employees that enhance the productivity of employees and ultimately organization performance boost.

Practical Implication: This study is helpful for top and middle level management to formulate and implementing the strategies to achieve organizational goals efficiently and effectively. The participative and consultative management styles succeed when the management feels that sharing of information will influence the employee's commitment and enhance the productivity. Organization in Azad Kashmir can use Consultative management approach for the development of employee and it is only possible if they are aware about the need and want of the employees. For this purpose it requires constant dialogue with the employees and clarifies the goals and objectives. Due to the BSC the motivation of the employee will increase and they will strive to do work efficiently. The use of BSC in Azad Kashmir is limited and organization doesn't provide reward on the basis appraisal. Top management in Azad Kashmir organizations should adopt BSC approach to enhance the performance of employees.

Future Research and Limitations: The area of research is limited due to small size of sample and time constraint. The service sector is a huge sector in the economy but selected area is banking sector in Azad Kashmir. Other variables can be used to determine the organization performance and satisfaction of employees. The working condition and culture of organization also affect the performance. Open ended questions can be used for getting the information about organization. Comparative study can be done with other organizations. Longitudinal approach can also be used to measure the performance of organization.

\section{Reference}

Barringer, B. R. \& Bluedorn, A. C. (1999). The relationship between corporate entrepreneurship and strategic management. Strategic Management Journal, 20(5), 421-444.

Belardo, S. \& Belardo, A. W. (2002). Innovation Throug Learning:What Leaders Need to Know in The 21ist Century. Whitston Publishing Company, Albany, NY.

Brown, M. G. (2000). Winning Score: How to Design and Implement Organizational Scorecards. Productivity Press, Cambridge, MA.

Bryson, J. M. \& Bromiley, P. (1993). Critical factors affecting the planning and implementation of major products. Strategic Management Journal, 14, 319-337.

Cappelli, P. (2000). Managing without Commitment. Organizational Dynamics, 28(4), 11-24.

Chorengel, S. \& Teare, R. (1994). Developing a responsive global network of Hyatt Hotels \& Resorts. In R. Teare \& M. D. Olsen (Eds.), International hospitality management: Corporate strategy in practice, 339-345. 
Cloudhury, V. \& Sampler, J. L. (1997). Information specificity and environmental scanning: An economic perspective. Management Information Systems Quarterly, 21(1), 25-53.

Davis, T. R. V. (2001). Integrating internal marketing with participative management. Management Decision, 39(2), 121-130.

Dev, C. S. \& Olsen, M. D. (1989). Environmental uncertainty, business strategy and financial performance: an empirical study of the US lodging industry. Journal of Hospitality and Tourism Research, 13(3), 171186.

Dooley, R. S. \& Fryxell, G. E. (1999). Attaining decision quality and commitment from dissent: The moderating effects of loyalty and competence in strategic decision-making teams. Academy of Management Journal, 42(4), 389-402.

Forbes, D. P. \& Milliken, F. J. (1999). Cognition and corporate governance: Understanding boards of directors as strategic decision-making groups. Academy of Management Review, 24(3), 489-505.

Garvin, D. A. (2000). Learning in Action: A Guide to Putting the Learning Organization to Work. Harvard Business School Press, Boston, MA.

Ghobadian, A. \& Gallear, D. (1997). TQM and organization size. International Journal of Operations \& Production Mangement, 17(2), 121-163.

Gmur, B. Bartlet, A. \& Kissling, R. (2010). Organization from a systematic Perspective: Application of the viable system model to the Swiss Youth Hostel Association.Kybernetes, 39(9/10), 1627-1644.

Haapasalo, H. Ingalsuo, K. \& Lenkkeri, T. (2006). Linking strategy into operational management: a survey of BSC implementation in Finnish energy sector. Benchmarking: An International Journal, 13(6), 701717.

Harrington, R. J. (2004). The environment, involvement, and performance: Implications for the strategic process of food service firms. International Journal of Hospitality Management, 23(4), 317-341.

Harrington, R. J. \& Ottenbacher, M. C. (2009). Decision-making tactics and contextual features: Strategic, tactical and operational implications. International Journal of Hospitality and Tourism Administration, 10(1), 25-43.

Joiner, T. A. (2007). Total quality management and performance. International Journal of Quality and Reliability Management, 24(6), 617-627.

Kolsaker, A. \& Lee-Kelley, L. (2008). Citizens' attitudes towards e-government and e-governance: a UK study. International Journal of Public Sector Management, 21(7), 723- 738.

Lawrie, G. \& Cobbold, I. (2004). Development of the $3^{\text {rd }}$ generation Balanced Scorecard. 2GC Active Management, Maidenhead, available at: www.2gc.co.uk/pdf/2GC-W0412.pdf.

Learnmangement2.com http://www.learnmarketing.net/

Maisela, T. (1995). Participative management facilitates a productive workplace. Human Resource Management, 11(5), 20-28.

Martell, R. F. Lane, D. M. \& Emrich, C. G. (1996). Male- Female difference: A computer simulation. American Psychologist, 51, 157-158.

Make coaching count (2006). Development and Learning in Organization, 20(5), 24-27.

Malmi, T. (2001). Balanced Scorecards in Finnish companies: a research note. Management Accounting Research, 12(2), 207-220.

Marsick, V. E. \& Watkins, K. E. (2003). Demonstrating the value of an organization's learning culture: the dimensions of the learning organization questionnaire. Advances in Developing Human Resources, $5(2), 132-151$.

Mintzberg, H. (1973). Strategy-making in three modes. California Management Review, 16(2), 44-53.

Nafukho, F. M., Graham, C. M. \& Muyia, M. H. (2009). Determining the relationship among organizational learning dimensions of a small-size business enterprise. Journal of European Industrial Training, 33(1), 32-51.

Niven, P. R. (2005). Driving focus and alignment with the Balanced Scorecard. The Journal for Quality and Participation, Winter, 21-25.

Northouse, P. G. (2004). Leadership theory and practice (3rd ed.). Thousand Oaks, CA: Sage Publications.

Ogbeide, G. A. Groves, J. \& Cho, S. (2008). Leadership Styles of Foodservice Managers and Subordinates Perceptions. Journal of Quality Assurance in Hospitality and Tourism, 9(4), 317-336.

Okumus, F. (2003). A framework to implement strategies in organizations. Management Decision, 41(9), 871882. 
Oosthuizen, G. J. \& Du Toit, A. S. A. (1999). Participative management in academic library services. Library Management, 20(4), 213-219.

Ottenbacher, M. \& Harrington, R. J. (2008). German culinary innovation processes: Differences in involvement and other factors. Journal of Foodservice Business Research, 11(4), 412-438.

Reddick, C. G. (2011). Citizen Interaction and e-government, Transforming Government: People. Process and Policy, 5(2), 167-184.

Schmelzer, C. D. \& Olsen, M. D. (1994). A data based strategy implementation framework for companies in the restaurant industry. International Journal of Hospitality Management, 13(4), 347-359.

Simons, T. Pelled, L. H. \& Smith, K. A. (1999). Making use of difference: Diversity, debate, and decision comprehensiveness in top management teams. Academy of Management Journal, 42, 662-673.

Smylie, M. A. Lazarus, V. \& Brownlee-Conyers, J. (1996). Instrumental outcomes of school based participative decision making. Educational Evaluation and Policy Analysis, 18, 181-191

Snyder, W. M. \& Cummings, T. G. (1998). Organizational learning disorders: conceptual model and intervention hypotheses. Human Relations, 51(7), 873-895.

Sorensen, P. F. \& Minahan, M. (2011). McGregor's Legacy: the evolution and current application of Theory Y management. Journal of Management History, 17(2), 178-192.

Teare, R. E. Costa, J. \& Eccles, G. (1998). Relating strategy, structure and performance. International Journal of Contemporary Hospitality Management, 10(2), 58-77.

The European Observatory for SMEs (1995). Third Annual Report, EIM Small Business and Research Consultancy, The Netherlands.

Valmohammadi, C. \& Servati, A. (2011). Performance measurement system implementation using Balanced Scorecard and statistical methods. International Journal of Productivity and performance Management, 60(5), 493-511.

Young, E. D. Coutts, D. W. \& Kapitan, D. (1998). UV laser ablation and irm-GCMs microanalysis. Geochimica et Cosmochimica Acta, 62(18), 3161-3168. 